возрождается в пику цифровизации, диалоги городского коммуникационного пространства советского времени обретут новое звучание и новый смысл.

\section{Vladimir Nazarov}

economist, marketer, Member of the Council of the Guild of marketers

of the Russian Federation, Member of the Union of journalists of Russia (Moscow)

vlad284@mail.ru

\section{Words, you won't say}

Everyday life of the Soviet past brought into the world cultural codes and behavioral stereotypes, which today evoke not only nostalgic memories of people born in the USSR, but also the time-honored interest of new generations, who are are attracted by the anthropology of Sovietism.

Keywords: anthropology of Sovietism, socio-cultural space of the city, communicative behavior, communicative environment, cultural code, reconstruction

\section{Елена Теплова}

\section{Визуальные образы советского детства}

Продолжая серию статей по антропологии образования, автор рассматривается вопрос об использовании визуальных образов детей как способа формирования представления о «счастливом советском детстве» с целью воспитания достойного гражданина советской страны.

Ключевые слова: советское детство, визуальные образы, дети, подростки, молодежь, кино, живопись, идеология, позитивная визуальная символика, плакат, счастье, мифологема «счастливое советское детство», образ ребенка

Во второй половине прошлого века в СССР активно создается идеологическая установка «счастливое советское детство», отражающая ценности и нормы, касающиеся детей и подростков. Воспитательные идеи и технологии, как и в любом обществе, в Советском Союзе
Теплова Елена Феликсовна, кандидат исторических наук, доцент кафедры культурологии, заместитель директора Центра историко-культурных исследований религии и межцивилизационных отношений, Институт социально-гуманитарного образования, Московский педагогический государственный университет (Москва),ef.teplova@mpgu.su были связаны с представлениями о будущем и о значимости детства как определяющего этапа формирования личности.

Общепринятые нормы предписывали, как должен выглядеть маленький или взрослеющий ребенок Страны советов, какие черты характера и занятия для него предпочтительны, а какие недопустимы; как он должен взаимодействовать со старшими и младшими; что нужно запрещать и что поощрять. Все это создавало особую воспитательную систему, отражавшуюся во всех социальных сферах - образовании, искусстве, семейных отношениях, моде, идеологии и т. д. [3].

Все сферы общественной жизни должны были укреплять и активно демонстрировать (если не удавалось полностью, по сути, соответствовать) ценностную модель советского детства, которая определялась официальной общественной идеологией. Огромная роль в этом отводилась внешним образам детей и подростков. Сохраняя идеи политики «монументальной пропаганды», провозглашенной в первые месяцы существования советской власти, визуализации, внешним формам придавалось особое значение. Ребенок, окруженный зрительными образами положительных, радостных, здоровых детей, должен был не только ощущать себя сопричастным к счастливому дет- 
ству, но и стремиться соответствовать этому образу. И эта политика приносила свои плоды. Сегодня в интернете можно найти множество сайтов и сообществ, которые обмениваются воспоминаниями, фотографиями, мыслями, главный смысл которых - ностальгия по собственному советскому детству.

Советская культура и искусство активно формировали самобытную картину детского счастья, определявшегося положительной эмоциональной оценкой собственной судьбы. Именно поэтому в сознании взрослых постсоветского периода прочно укоренилось представление о детстве в СССР как о самой счастливой поре жизни.

В основе мифологемы «счастливое советское детство» [4] лежала идея воспитания «нового» советского человека, свободного от предрассудков и недостатков предшествующей эпохи, активного строителя счастливого будущего.

Повсеместное использование позитивной визуальносимволической культуры советского детства способствовало формированию своеобразного и устойчивого канона изображения «счастливых» советских детей, а также активному усвоению официально принятых норм и ценностей. Детские образы использовались повсеместно как иллюстрации к лозунгу «Счастливое детство в советской стране», что нашло свое отражение во всех визуальных жанрах советской эпохи: в книгах и учебниках, плакатной графике, игрушках, марках, открытках, мультфильмах [5], кино, фотографиях, живописи, скульптуре. Важно, что весь этот визуальный ряд прежде всего был адресован самим детям.

Первое, с чем сталкивался ребенок, - это игрушки. Советские игрушки выполняли не только развивающую, но и очевидно воспитательную, дидактическую функцию. Впервые образ ребенка встречался в куклах.
Советская кукла была скромна и непритязательна, гармонична по своей форме, как правило, со светлыми волосами, одетая в простое платье. Это был первый образ для девочек, для мальчиков советская промышленность изготавливала солдатиков. Будущий гражданин Страны советов должен был готовиться не только трудиться на благо своей Родины, но и защищать ее. Все изображения детей с игрушками показывали здоровых, упитанных дошкольников с куклой, мишкой или зайкой, машинкой или ракетой в руках. Ребенок должен быть благонравен и приятен глазу: девочки обязательно были причесаны - бантики, косички или аккуратные стрижки, мальчики коротко подстрижены. Все дети были одеты скромно, но добротно, выглядели они сытыми, здоровыми и веселыми.

Образ советского детства активно тиражировался на открытках и иллюстрациях. Тематика изображений разнообразна, но предсказуема: мать и дитя (образ счастливого материнства); дошкольники с игрушками, школьники (их всегда было легко узнать по форме); играющие или занимающиеся спортом дети; дети на праздниках (чаще всего Новый год, Первое мая, Восьмое марта). Подобные образы присутствовали и на плакатах. Плакаты играли огромную роль в культурном пространстве Советского Союза. Издававшиеся многомиллионным тиражами они окружали граждан СССР везде: на улице, на работе, в школе, в поликлинике, Доме культуры, воинской части, местах заключения и т. д. Именно плакаты как элементы культурной среды в значительной мере формировали общественное сознание и в том числе, оказывали влияние на представление о советских детях.

Весь окружавший гражданина СССР визуальный ряд был призван формировать нового человека. Это понималось не только как следствие, но и как условие 
успешного строительства коммунизма. Советский ребенок был всегда узнаваем и на плакате, и на открытке, и на книжной иллюстрации, и даже в елочной игрушке. Упитанный, скромно, но аккуратно одетый и причесанный, веселый - такой малыш символизировал собой собирательный и идеальный образ ребенка Страны советов. Можно сказать, что это был фактически образец для подражания. Таких детей хотели видеть и всеми возможными визуальными средствами старались привить стремление соответствовать этому образу. Плакат показывал, каким должен быть советский ребенок, выделяя желаемые положительные черты, которыми он должен обладать. Радостный, ведущий здоровый образ жизни, с интересом относящийся к учебе (плакат «Если хочешь быть здоров - закаляйся» 1950 г., авторы: В. Грицевич, В. Корецкий; «Все умеем делать сами. Помогаем нашей маме!» 1960 г., авторы: Н. Вигилянская, Ф. Качелаев). Черты, не соответствующие идеалу, высмеивались («Не будь таким!» 1957 г., авторы: К. Иванов, В. Брискин; «Не смей» 1955 г. С. Низовой.).

Еще одним мощным каналом трансляции образов советского детства был кинематограф. Кино, как наиболее мобильный и массовый вид искусства всегда отражает процессы, происходящие в обществе, и активно влияет на общественное сознание.

Детские образы в советском кинематографе должны были всячески поддерживать мифологему «счастливого советского детства», «согласно которой коллектив детей, создав отделенный от взрослых игровой авантюрный мир, помогая друг другу в трудных ситуачиях, сочиализируются в прочессе своей игры даже лучше, чем, если бы их воспитывали взрослье. Ребенок, как одна из сочиальных иенностей, залог будущего новой советской России - ведущий мотив твориества режиссеров-кинематографистов указанного периода» $[4$, с. 6$]$.
В 1960-е гг. появляется так называемый «проблемный фильм», в котором присутствуют не только положительные, но и отрицательные герои, нередко получавшие на экране комедийные характеристики. Например, фильм Элема Климова «Добро пожаловать, или Посторонним вход воспрещен» 1964 г.

Детское кино не только работало на образ «счастливого детства», в нем четко определялись герои, на стороне которых должны были быть симпатии зрителей. Важной становится тема самореализации личности и ее ответственности за будущее своей страны. Смысл детского счастья в кино связывался с такими ценностными категориями, как дружба, честь, добро, преданность долгу. Счастье для советских детей - это крепкая дружба, свобода в принятии решений (при умении «поступать правильно»), уважение товарищей.

В советском кинематографе периода застоя «счастливое детство» отражалось и иллюстрировалось жизнью детского коллектива, который создает отделенный от взрослых игровой авантюрный мир, открывает и осваивает ценности «взрослой» советской жизни как подлинные [4]. Такие дети, помогая друг другу в трудных ситуациях, решая неоднозначные нравственные вопросы, взрослеют и социализируются, формируются как идеальный образ юного советского гражданина. Кино играло важную роль в досуге и ментальности советских детей и подростков, на положительных героев фильмов стремились быть похожи, искренне, до слез переживали события кинокартин, которые смотрели по многу раз. Посмотреть фильм можно было или в кинотеатре, или по телевизору. Выход каждого фильма, адресованного детской аудитории, по сути, был всесоюзной премьерой, его смотрели все, хорошо знали сюжет, постоянно цитировали. Цитаты из фильмов своего детства сегодня часто можно услышать от россиян пен- 
сионного и предпенсионного возраста. Усвоенное в детстве стойко сохраняется в сознании наших сограждан, причем эти воспоминания практически всегда носят позитивный характер.

Мир ребенка подразумевает наличие сказочного пространства. Эта среда складывалась для советских детей в основном из книг, кино, диафильмов, мультипликации и театральных постановок. И во всех случаях образ положительного героя наделялся чертами советского пионера или школьника. Фильм «Три толстяка», снятый в 1966 г. по сказочной повести Ю. Олеши режиссерами А. Баталовым и И. Шапиро, показывал детей, помогающих взрослым победить тиранов. Открытые лица, добрые сердца, пламенные речи и готовность бороться за правое дело. В случае если герой попадал в сказочный мир, как например в книге В. Губарева «Королевство кривых зеркал» или повести «Старик Хоттабыч» Л. Лагина, победа над злом и торжество добра и справедливости обеспечивалось качествами главных героев, которые полностью соответствовали образу «советского детства». Антиподы - дети, не соответствующие этому образу, несли заслуженное наказание и исправлялись. В фильмах, снятых по этим книгам режиссерами Г. Казановским в 1956 г. и А. Роу в 1963 г. героями были советские школьники, о чем все время напоминала их школьная форма, они боролись с пороками и одерживали победы, в том числе и над собой.

Советский детский фильм всегда дидактичен: в образах сказочных героев, которых в кино играли юные исполнители, так же угадывались черты «хороших» и «плохих» детей. Примером может служить фильмы «Приключения Буратино» (1975, режиссер Л. Нечаев), «Морозко» (1964, режиссер А. Роу), «Двенадцать месяцев» (1972, режиссер А. Граник). Во всех волшебных сказках и приключенческих историях, написанных и снятых для советских детей, неизменно можно было найти героя, чей характер и внешний вид отсылал к собирательному образу идеального советского ребенка или подростка. Завуалированно подчеркивалось, что герой добивался победы именно благодаря таким качествам, которые стремится воспитывать в детях советское общество и советская школа.

Визуальные образы советского детства были адресованы не только детям, но и взрослым, и прежде всего родителям. Именно в кино зарождается и активно развивается идея перевоспитания родителей детьми. Юный герой, обладающий яркими качествами советского человека, устремленный в будущее и готовый за него бороться, оказывает влияние и на позитивные изменения своих родителей. Это фактически была серьезнейшая идеологическая установка, на реализацию которой работали в том числе визуальные образы. В кино дети или замещают взрослых в серьезных делах, или воспитывают их своим примером и, разумеется, учатся в школе и стремятся к знаниям. Подросток, выросший на определенной идеологии, становится ее проводником. Взрослые должны были стремиться создавать для ребенка такие условия, чтобы он выглядел и действовал в соответствии с парадигмой советского детства. Такие образы присутствуют во многих «взрослых фильмах»: «Мачеха» (1973, режиссер О. Бондарев), «Дети Дон-Кихота» (1966, режиссер Е. Карелов), «Бриллиантовая рука» (1968, режиссер Л. Гайдай). Образы советских детей как важнейшего достижения советского общества находили свое отражение в кино, в мультипликации («Цветик-семицветик» 1948 г., «Вовка в тридевятом царстве» 1965 г.), живописи, скульптуре и книжной иллюстрации.

Монументальная пропаганда советского образа жизни работала весьма активно, узнаваемый образ 
детей и подростков встречался в парках и скверах, которые украшались уличной скульптурой, на мозаиках и панно зданий, в декоре московского метро. Все эти дети были красивыми, аккуратно одетыми и причесанными, увлеченные делами и учебой, радостными, абсолютно здоровыми. Скульптура и барельеф, выполняя основную идеологическую задачу, передавали образы емко и цельно, а вот живопись советского периода стремилась обогатить внешний облик детей и внутренним содержанием, используя для этого все возможные художественные приемы. Мир детства, изображавшийся в период 1950-1980 гг., был иллюстрацией счастливого детства в советской стране. Темой живописных полотен становились повседневные жизненные ситуации: школьная жизнь, занятия спортом, увлечения, семья, дружба народов СССР и, конечно, материнство. Живопись советского периода проводила главную мысль в Советском Союзе созданы все условия для счастья семей и детей. Конечно, әто был идеал, к которому нужно было стремиться. При этом многие художники старались передать внутренний мир ребенка, его эмоции, радость или огорчение [6]. Все произведения с изображением детей «пронизаны спокойствием, состоянием безмятежности и любви, ощущением заботы и защищенностью их любящими родителями» [5].

То, каким будет детство, зависит от взрослых. Образы взрослых, сопровождающие детей в живописи, на плакате и в кинофильмах, соответствовали идее, что такие взрослые обеспечивают счастливое советское детство, и это прежде всего родители и учителя. Заботливые отцы и нежные матери, всем своим обликом соответствовали идеальным детям, которые были будущим образцом взрослого советского человека. Таковы соцреалистические полотна В.П. Кучеренко «Семья», 1967 г.; Н.В. Овчинникова «Первенец», 1963 г.
Большую роль в воспитании подрастающего поколения играла школа, пионерская и комсомольская организация. Эта тематика так же отражалась в советской живописи. Учитель олицетворял состоявшегося взрослого, сопровождающего ребенка, направляющего его и сопереживающего его успехам (Н.И. Терещенко «Заслуженная учительница», 1953 г.; А.П. Суворова «Уроки химии в школе», 1974 г.).

Знакомая каждому картина $\Phi$. Решетникова «Опять двойка» (1952) - своего рода визуальный мем советской эпохи, постоянно использовавшийся для иллюстрации нравственных поступков детей. Она была напечатана в учебнике для младших школьников «Родная речь» и сегодня используется авторами учебников по «Основам светской этики» и учебника по русскому языку для шестиклассников. Это полотно отражает непростую ситуацию в жизни ребенка, получение неудовлетворительной оценки - ситуация негативная, крайне нежелательная, но при этом обыденная. Главный герой, обыкновенный школьник, расстроен неудачей. Все участники события также соответствуют образу советской семьи, причем вполне обеспеченной: мебель, ковер, часы, велосипед. Антиподом двоечника выступает его сестра-пионерка, хорошая ученица - она, как и мама, осуждает своего брата и переживает за него. Эта работа $\Phi$. Решетникова является второй в трилогии о советском детстве, причем первая картина цикла «Прибыл на каникулы» (1948), присутствует здесь в виде репродукции на стене. Но и картина «Опять двойка», в свою очередь, становится репродукцией на стене в третьем полотне этой трилогии «Переэкзаменовка» (1954). Мальчик получил плохую оценку не потому, что он слабый ученик, о нем плохо заботятся или плохо учат в школе, а потому, что выполнению задания он предпочел коньки. Занятия спортом - частый сюжет живописи 
о советских детях (В. Жолток «Зима пришла», 1955; И. Городецкая «На старте», 1958). Школьник из «Переэкзаменовки» обязательно справится со своей ошибкой и станет учеником, достойным страны советского детства, таким, как изображались пионеры во всех жанрах визуального воздействия. Несомненно, реальная жизнь глубже, богаче и разнообразнее визуального канона, и жизнь детей в СССР не всегда соответствовала провозглашенному идеалу.

Цель воспитания, как и визуальных образов, - пропаганда советской идеологии и советского образа жизни. Молодой человек как представитель новой идеологии олицетворял идеальное будущее. Но как показала история, будущее оказалось совсем не таким, как его представляли. Свойственный молодежи протест против стандартов и косности старших, в том числе собственных педагогов, впервые нашел отражение в фильме «Доживем до понедельника» (1968 г., режиссер С. Ростоцкий). Постепенно в кино, литературе и драматургии начнет возникать иной образ подростка, молодого человека, отрицающего общепринятые нормы и ценности, стремящегося уклониться от общей поведенческой парадигмы и идти своим путем. Постепенно стали меняться и образы детей, ярким примером может служить фильм «Чучело», снятый Роланом Быковым в 1983 г.

Визуальный образ «счастливого детства», повсеместно транслируемый в СССР в 1950-1970 годы, выполнял важную стратегическую и педагогическую функцию, он был адресован главным образом несовершеннолетним гражданам страны, наиболее восприимчивым к конструированию новой идеологии. Утрата идеала, несоответствие реальной жизни обещанной мечте является сегодня основной причиной ностальгии по советскому прошлому у многих российских граждан, чьи детские годы прошли в СССР.

\section{תumepamypa:}

1. Артемьева Е.А. Детские и подростковые образы в советском кинематографе: культ юности и страх перед ней // Вестник московского университета. Сер. 9. Филология. 2013. № 3. С. 154-159.

2. Вачаева Л.А. Образ ребенка и мир детства в изобразительном искусстве России советского периода // Культура. Духовность. Общество. 2015. № 20. URL: https:// cyberleninka.ru/article/n/obraz-rebenka-i-mir-detstva-v-izobrazitelnom-iskusstverossii-sovetskogo-perioda (дата обращения: 05.05.2020)

3. «Гуляй там, где все»: История советского детства: опыт и перспективы исследования. Коллективная монография / Сост.: В.Г. Безрогов, М.В. Тендрякова; Редкол.: М.Р. Балина, В.Г. Безрогов, К. Келли, А.А. Котомина и др. М.: РГГУ, 2013. 442 с. (Труды семинара «Культура детства: нормы, ценности, практики». Вып. 14)

4. Зайцева И.А. Мифологема «счастливое детство» в советском кинематографе 1920-1980 гг.: ценностный аспект // The childhood, adolescence and youth in a context of scientific knowledge : materials of the VI international scientific conference on April 25-26, 2016. Prague: Vědecko vydavatelské centrum «Sociosféra-CZ», 2016. C. 5-10.

5. Лефман Т.О. Образ детства как объект конструирования в отечественной анимации // Вестник культуры и искусства. 2019. № 1 (57). С. 137-143.

6. Окольская Л.А., Пешкова В.М. Нормативные визуальные образы в массовой культуре для подростков // Общественные науки и современность. 2012. № 3. С. 156-167.

\section{Иллюстрачии:}

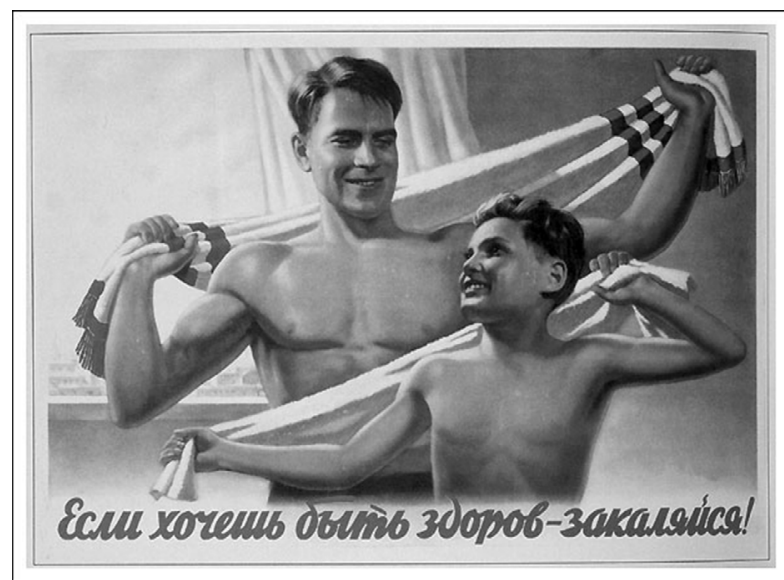

Виктор Корецкий, Вера Грицевич,

плакат «Если хочешь быть здоров, закаляйся!». 1950. 


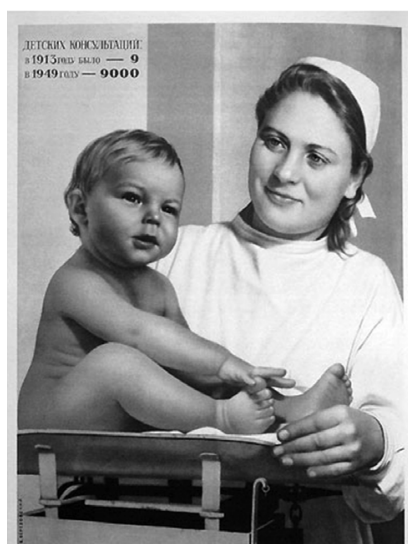

РАСТИ, БОГАТЬрम

Борис Березовский, плакат «Расти, богатырь». 1950.

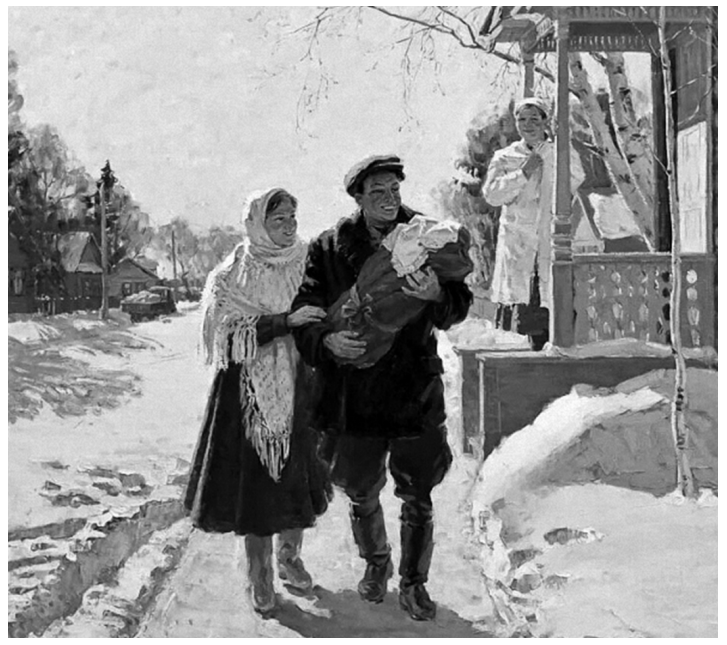

Николай Овчинников, «Первенец». 1963. X., М.

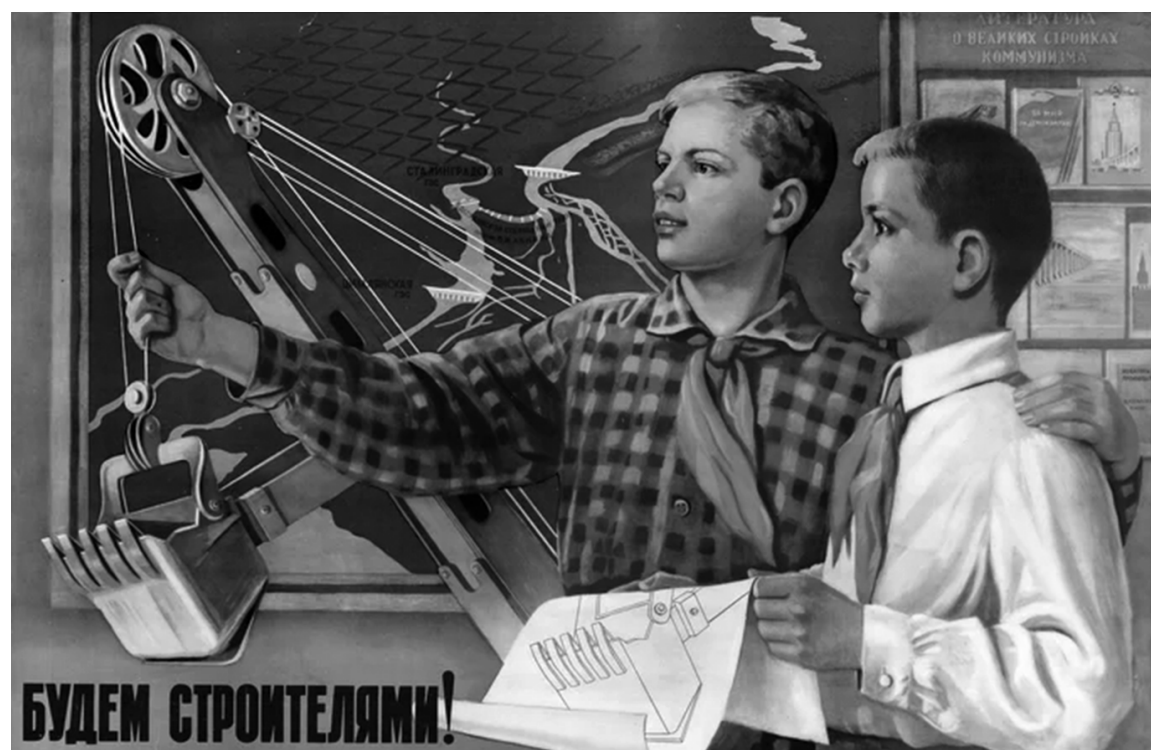

Мария Бри-Бейн, плакат «Будем строителями!». 1953.

154
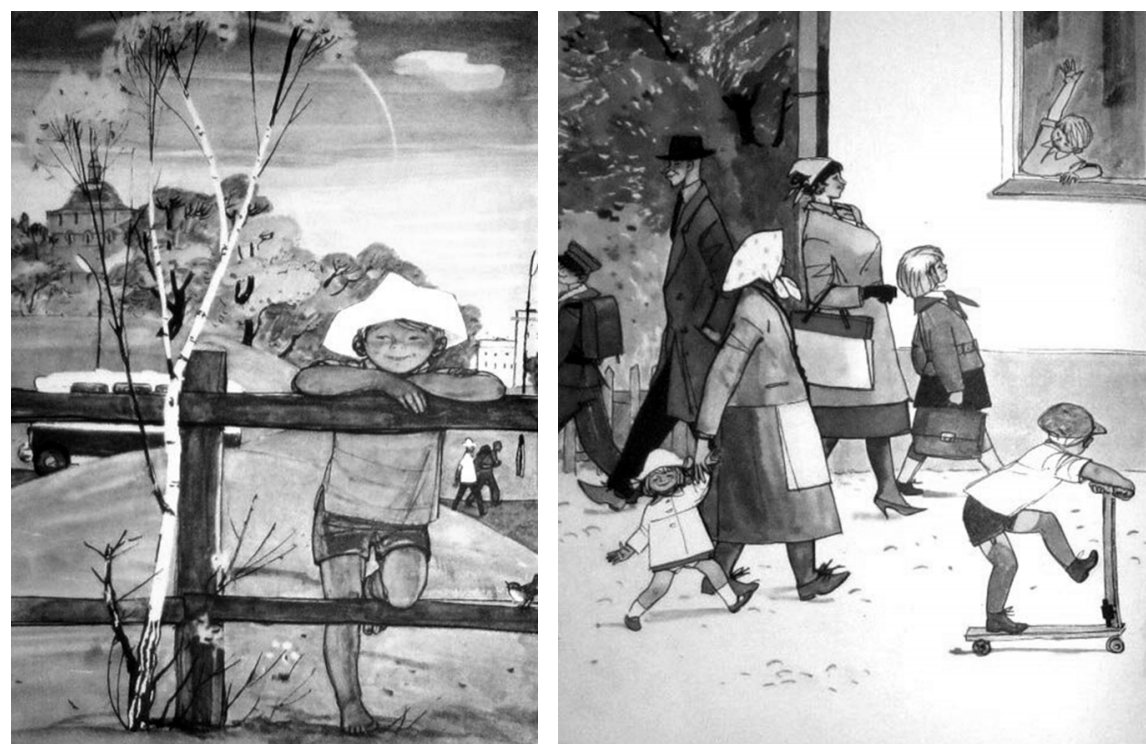

Федор Лемкуль, иллюстрации к книге Агнии Барто «Вовка - добрая душа» (М.: Детская литература, 1968).

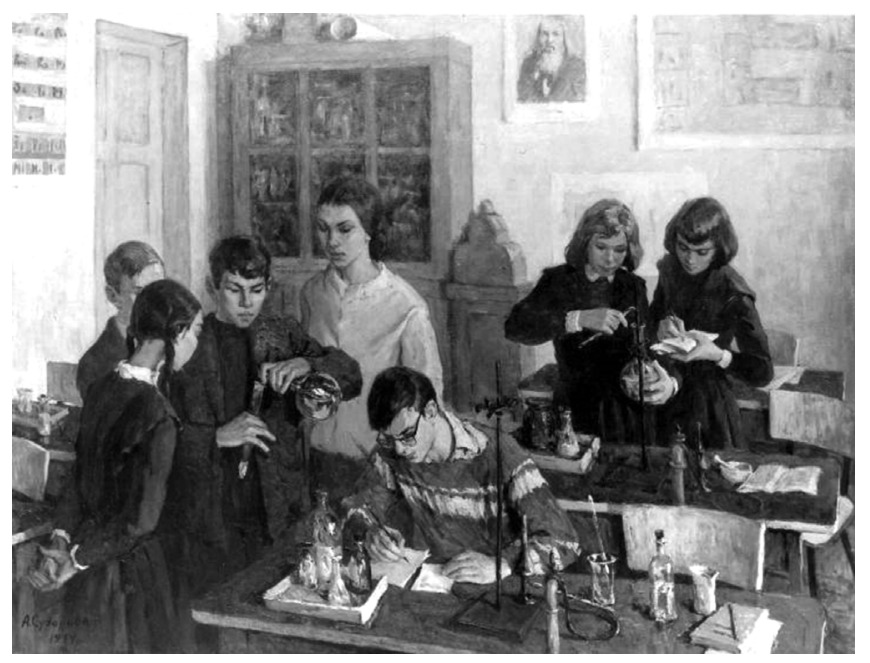

Анна Суворова, «Уроки химии в школе». 1974. Х., м.

Альманах «ЭТНОДИАЛОГИ» №3 (61) 2020

155 


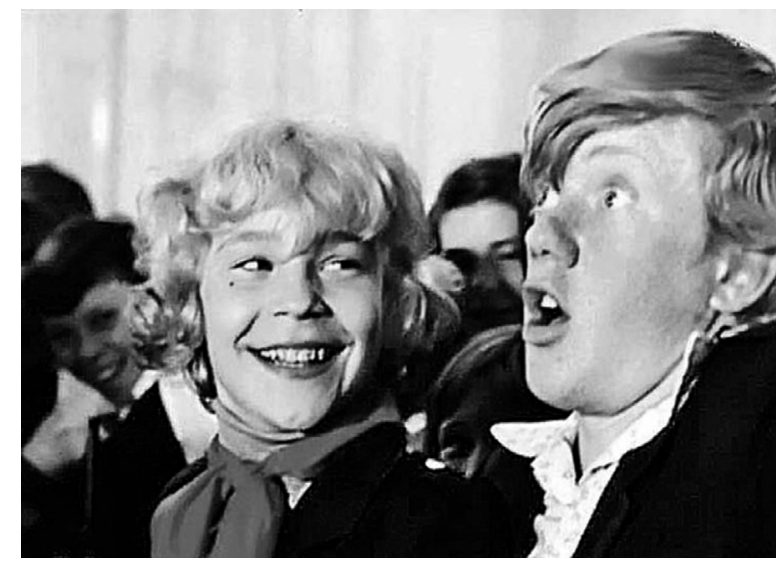

Кадр из детского музыкального фильма

«Приключения Электроника» («0десская киностудия», 1979. Режиссер Константин Бромберг)

\section{Elena Teplova,}

Ph.D. in History, Associate professor at the Department of cultural studies,

Deputy Director, Center for historical and cultural studies of religion

and intercivilizational relations, Institute of Social and Humanitarian Education

Moscow Pedagogical State University (Moscow)

ef.teplova@mpgu.su

\section{Visual patterns of Soviet childhood}

Continuing a series of articles on the anthropology of education, the author considers the use of children's visual patterns as a way to form an idea of a «happy Soviet childhood» in order to educate a decent citizen of the Soviet country.

Keywords: Soviet childhood, visual patterns, children, teenagers, youth, cinema, painting ideology, positive visual symbols, poster, happiness, happy childhood concept

\section{НАСЛЕДИЕ}

Фарида Мир-Багирзаде

\section{Литературные произведения в азербайджанской анимации: символика и семантика}

При помощи сравнительно-исторического анализа автор исследует азербайджанские мультипликационные фильмы, экранизирующие произведения как отечественной, так и зарубежной литературы. В процессе создания каждого рисованного мультфильма советской эпохи принимали участие профессиональные режиссеры, сценаристы, художники-постановщики, снимавщие анимационные фильмы по произведениям азербайджанских писателей-классиков, среди которых - Низами Гянджеви, Мухаммед физули, Сеид Азим Ширвани, Мирза Алекпер Сабир, Джалил Мамедкулизаде, Абдулла Шаиг, Сулейман Сами Ахундов, Али Керим, Расул Рза. К числу азербайджанских мультфильмов, снятых по произведениям зарубежной литературы, относится экранизация «Звездных дневников Ийона Тихого» и анимационный фильм по мотивам японских хайку. Азербайджанские мультфильмы по мотивам литературных произведений, вошедшие в золотой фонд киноискусства Азербайджана, отличаются специфическим творческим методом.

Ключевые слова: мультфильм, сюжет, постановка, художник, сценарий, литературное произведение, художественный образ, наследие, азербайджанская мультипликация, «Азербайджанфильм»

\section{Мир-Багирзаде Фарида} Алтай кызы,

кандидат искусствоведения

(доктор философии в области искусствоведения), дочент

по эстетике, ведущий научный сотрудник отдела «Изобразительные, декоративноприкладные искусства и геральдика» Института архитектуры и искусства

Национальной академии наук Азербайджана (Баку), faridamb2013@gmail.com
Болгарский режиссер Тодор Динов считал, что построение мультипликационного образа определяется пятью факторами: 1) литературной основой, в которой заданы особенности образа; 2) рисунками художника, который будет заниматься созданием внешнего облика образа; 3) актерским мастерством мультипликатора, который оживит образ; 4) звуковым решением образа; 5) производственной спецификой мультипликационного искусства. 